\title{
Engineering Leadership Education: Catalyzing Long-Term Personal and Professional Growth
}

\author{
Annie Simpson, Douglas W. Reeve, Cindy Rottmann, Qin Liu, \\ Victoria Hue and Samuel McCullouch \\ Troost Institute for Leadership Education in Engineering, University of Toronto
}

\begin{abstract}
The Troost Institute for Leadership Education in Engineering (Troost ILead) has been actively engaged in developing the leadership capacity of engineers since its inception of 2002. Through a suite of leadership programming - both curricular and co-curricular, a robust research team, and our active industry-university Community of Practice we work towards our vision of engineers leading change to build a better world.' After 16 years of dedicated work, we conducted a mixed method study to discover and understand the lasting impact of our work. 806 alumni responded to our survey and 25 interviews were conducted. This study provides evidence that engineering leadership programming can and does catalyze long-lasting personal and professional growth for undergraduate and graduate students. This paper presents our findings and the implications for engineering leadership education.
\end{abstract}

KEYWORDS: engineering leadership, alumni study, leadership-identity, program evaluation

\section{INTRODUCTION}

At the Troost Institute for Leadership Education in Engineering (Troost ILead) we have been actively engaged in developing the leadership capacity of engineers since 2002. Through leadership programming activities - both curricular and co-curricular [1,2], classroom and workplace research projects [3-18], and our industry-university Community of Practice we work towards our vision of 'engineers leading change to build a better world.' Programming for students is delivered through 15 high-demand courses, a range of co-curricular initiatives and by integrating leadership learning into core courses across the Faculty. Troost ILead's approach to leadership emphasizes four domains of learning: Self, Team, Organization and Society.

After 16 years of programming work, we conducted a mixed method study to discover and understand the impact of our work. In the summer of 2018 we designed and administered an online survey to 4356 alumni

CEEA19

University of Ottawa; June 9-12, 2019 (including some current students), and received responses from 806 individuals, resulting in a response rate of $19 \%$. In addition, we conducted qualitative interviews with 25 key informants. This paper presents our findings and discusses the implications of these findings for engineering educators and for the growing field of engineering leadership. In particular, our paper responds to the following research question: How did alumni perceive the impact of ILead programming on their leadership development?

\section{PROGRAM CONTEXT}

Troost ILead's philosophy and approach to leadership education situates leadership as a process of influencing change independent of one's position [19]. We conceive of leadership occurring at four levels; namely self, team, organization and society. Self-leadership competencies include: definition of personal values, clarity on personal leadership strengths, and active engagement in selfreflection. At the level of team leadership, ILead works to promote empathy in teams, to support students to balance their awareness of both tasks and relationships, to leverage diverse skills and to navigate conflict effectively. In addition to our co-curricular programming, we have conducted research on student teamwork in engineering design projects [14-17, 20], and integrated the resulting system into the formal engineering curriculum. In the organizational domain we support student leaders (often positional leaders) to influence others, create organizational vision and to plan and organize events. Additionally, much of our research focuses on engineering leadership in industry, blending individual and organizational levels of analysis $[4,5,10,12,21]$. Finally, in the societal domain we encourage students to become engaged citizens, to advocate for diversity and social justice and to communicate their engineering know-how to guide positive change. We have also developed ethics and equity case studies to help them navigate challenging situations [8]. 


\section{METHODOLOGY}

Our survey was created with a desire to understand which Troost ILead courses and co-curricular programs our alumni had participated in and how their participation impacted their development in the four domains of leadership: self, team, organization and society. We asked the participants to rate the extent to which ILead programs helped them in 27 competency areas $(1=$ not at all; $5=\mathrm{a}$ great deal). We ran an exploratory factor analysis and found that the questions for the four domains of leadership had a high internal consistency (the Cronbach's alpha values were all above .90). We, therefore, created four composite scores to measure the four leadership domains. We compared the composite scores by the alumni's graduation year and type of engagement with ILead. We used the following indicators to examine learners' engagement: number of engagements, programmatic intensity (drop-in, certificate, cohort, full course), and type of engagement (curricular versus co-curricular, and graduate versus undergraduate courses). We used Cohen's $\mathrm{d}^{1}$ to measure the magnitude of the differences [22]. Additionally, to complement the quantitative analysis we conducted 25 interviews with alumni who volunteered to share their experiences and insights.

\section{QUANTITATIVE FINDINGS}

The first finding came as a surprise. When asked 'do you consider yourself to be a leader' (yes/no) $84 \%$ of the respondents indicated "yes." This shows a marked contrast to industry-based studies demonstrating professional engineers' resistance to the notion of engineering as a leadership profession $[12,23]$. Two quotes emerging from interviews with alumni, suggest that leadership was intimately connected to students' sense of themselves as engineers and as human beings. Please note that pseudonyms have been used for all alumni quotations.

"Engineering comes with this onus of leadership. Everyone is a leader. If you are an engineer, you are assuming leadership even if it's not your title. ILead opened my eyes towards that." (Tony, IndE 2018) "ILead has taught me the philosophy of leadership. This understanding about leadership is not merely a memorized knowledge, but a principle that deeply impacted various part of my life." (Yin, MSE, 2017)

This finding suggests - either that students who were interested in leadership were more likely to seek out our programing or that our programing contributed in a positive way to alumni's leadership identity development.

A second finding revealed that high-intensity student engagement translated into leadership development. We analyzed the difference in perceived impact among four groups: those who attended drop-in co-curricular workshops ( 2 hours), those who completed a co-curricular certificate program (8-10 hours), those who completed a co-curricular cohort-based program (20-30 hours) and those who participated in academic courses (40 class hours). The results revealed a significant difference in all four leadership domains between alumni who participated in the three lower intensity co-curricular programs and those who completed semester long leadership courses (see Table 1). Courses alone were associated with perceptions of higher leadership growth across all 4 domains, when compared to co-curricular programs, a finding that confirms Knight and Novoselich's 2017 study [24].

Table 1. Impact of co-curricular and curricular programs on perceived leadership development.

\begin{tabular}{|c|c|c|c|c|c|c|}
\hline \multirow[b]{2}{*}{ Impact measures } & \multicolumn{2}{|c|}{$\begin{array}{l}\text { Co-curricular programs } \\
\qquad(\mathrm{n}=87)\end{array}$} & \multicolumn{2}{|c|}{ Courses $(n=172)$} & \multirow[b]{2}{*}{$\mathrm{p}$ value } & \multirow[b]{2}{*}{ Cohen's d } \\
\hline & Mean & SD & Mean & $\mathrm{SD}$ & & \\
\hline Impact on self-leadership & 3.36 & 0.88 & 3.84 & 0.75 & $\mathrm{p}<. .001$ & 0.58 \\
\hline Impact on team leadership & 3.37 & 0.94 & 3.81 & 0.77 & $\mathrm{p}<. .001$ & 0.51 \\
\hline leadership & 3.06 & 1.08 & 3.34 & 0.96 & $\mathrm{p}<.05$ & 0.27 \\
\hline Impact on societal leadership & 2.99 & 1.08 & 3.43 & 0.96 & $\mathrm{p}<.01$ & 0.43 \\
\hline
\end{tabular}

Third, when analyzing the data, we found that alumni reporting the greatest impact across all four domains had

${ }^{1}$ Interpretation of Cohen's d: when the $d$ value is 0.2 , the effect size is small; a $d$ value of .5 represents a medium

CEEA19

University of Ottawa; June 9-12, 2019 engaged in both curricular and co-curricular programs (Table 2). Combined with the above finding, our survey

effect size; and a $d$ value of .8 means a large effect size (Cohen, 1977).

Cohen, J. (1977). Statistical power analysis for the behavioral sciences. New York, NY: Routledge. 
suggests that co-curricular programing supplements and enhances the positive impact students experience when engaging curricular leadership development offerings. This is important information for us to consider as we continue to grow our suite of offerings.

Table 2. Comparison by type of engagement: Alumni respondents only

\begin{tabular}{l|cc|cc|cc|c}
\hline & \multicolumn{2}{|c|}{$\begin{array}{c}\text { G1: Engaged in } \\
\text { co-curricular } \\
\text { activities only } \\
\text { (n=109) }\end{array}$} & \multicolumn{2}{|c|}{$\begin{array}{c}\text { G2: Engaged in } \\
\text { curricular } \\
\text { activities only } \\
\text { (n=167) }\end{array}$} & $\begin{array}{c}\text { G3: Engaged in } \\
\text { both co-curricular } \\
\text { and curricular } \\
\text { activities (n=101) }\end{array}$ & \\
\cline { 2 - 7 } & Mean & SD & Mean & SD & Mean & SD & p value \\
\hline Impact on self-leadership $^{\mathrm{a}}$ & 3.39 & 0.86 & 3.86 & 0.73 & 4.06 & 0.66 & $\mathrm{p}<.001$ \\
Impact on team leadership $^{\mathrm{b}}$ & 3.44 & 0.92 & 3.82 & 0.77 & 3.95 & 0.70 & $\mathrm{p}<.001$ \\
Impact on organizational leadership $^{\mathrm{c}}$ & 3.19 & 1.04 & 3.35 & 0.95 & 3.64 & 0.98 & $\mathrm{p}<.01$ \\
Impact on societal leadership $^{\mathrm{d}}$ & 3.08 & 1.09 & 3.46 & 0.94 & 3.63 & 0.96 & $\mathrm{p}<.001$ \\
\hline
\end{tabular}
a. $\quad \mathrm{G} 1<\mathrm{G} 2$, Cohen's $d=.60 ; \mathrm{G} 1<\mathrm{G} 3, \mathrm{~d}=.87$
b. $\quad \mathrm{G} 1<\mathrm{G} 2, \mathrm{~d}=.45 ; \mathrm{G} 1<\mathrm{G} 3, \mathrm{~d}=.87$
c. $\mathrm{G} 1<\mathrm{G} 3, \mathrm{~d}=.45 ; \mathrm{G} 2<\mathrm{G} 3, \mathrm{~d}=.30$
d. $\quad \mathrm{G} 1<\mathrm{G} 2, \mathrm{~d}=.37 ; \mathrm{G} 1<\mathrm{G} 3, \mathrm{~d}=.54$

\section{INTERVIEW FINDINGS}

We supplemented survey findings with themes emerging from our inductive analysis of 25 phone interviews. In particular, participants identified three salient areas of impact: 1) Troost ILead programming empowers students to be 'workplace ready.' 2) Troost ILead programming is a catalyst for 'self-discovery', and 3) Troost ILead encourages a 'broader view of engineer's responsibilities' towards guiding positive change in society.

To illustrate these three themes we have included a few quotes. Under the umbrella of 'workplace readiness' alumni repeatedly spoke of how Troost ILead had helped them with their interpersonal and professional growth. 'I recall sessions on how to grow your communication and leadership skills. Looking back, working full time, I find this so critical. These are the skills that matter later in your career.' (Rachelle, Chem, 2008)

'The process of goal-setting and reflecting in tandem has helped me to prioritize what I want to do in my life and understand the time it takes to do what I want to do. This helped to propel me to run my own company now, a few years after exiting school. The ILead course really changed my mindset to do things that were important to me and to act as fast as possible.' (Gord, IndE, 2017) 'It has helped me gain more self-confidence as a leader and build harmonious working relationships with the people around me.' (Katie, Chem, 2016)

CEEA19

University of Ottawa; June 9-12, 2019
The theme of 'self-discovery' was articulated by many interviewees in their comments on how ILead promoted self-reflection, self-awareness and personal growth. 'I found ILead to be very helpful for me both in terms of deepening my reflection and understanding myself and my own values. It helped me to understand the people-side of change and how important it is to understand that beyond the technical side. One of the biggest values of ILead is finding similarly interested colleagues to collaborate with and get to know. These are some of my best friends today, both a personal and professional support system.' (Amir, EngSci, 2009)

'My very first info session - it blew my mind that this opportunity existed. The opportunity to step away from math and science and to think about what the trajectory of my life could look like. I had thought that my success (whatever that meant) would be contingent on my grades, and at that point success didn't seem very likely. It only took an hour or so, but I knew that this way of thinking was something I strongly aligned with.' (Mathew, MSE, 2012)

The third consistent theme related to 'engineers responsibility to guiding positive change.' Alumni spoke of ILead turning students into leaders, creating community and empowering engineers to see engineering as a leadership profession, with important responsibilities to society.

'Through ILead, I became a bit more purposeful about what I wanted to do after [graduation]. I think that has really...helped me to see the importance of being in an organization that has values and beliefs that align with my own and integrating that in my approach to finding jobs 
and figuring out what my career would be and moving in that direction.' (Dora, IndE, 2016)

'Engineering leadership is a unique lens of technical and collaboration that is not about greed or self-importance or career advancement or money. It's about empowering people to collaborate with the goodness of society in mind.' (Jerome, Eng Sci, 2017)

\section{IMPLICATIONS AND NEXT STEPS}

When we asked our 806 respondents what they would like to see more of there were two consistent messages. The first was to integrate leadership education into core courses, and the second was to offer further educational opportunities to our alumni. While we have not yet developed significant opportunities for alumni to continue their leadership learning with us, we have made significant progress in the last two years with course integration work. In the academic year of 2018-2019, ILead integrated leadership learning (primarily focused on team work competencies and ethics and equity case studies) into 26 courses. Integrating leadership education into core courses is an opportunity to engage thousands of students each year and to build the socio-technical competencies required for engineers to be effective as leaders, employees and team members.

A finding from this survey that we will continue to integrate into our planning relates to the value of engaging students in both stand-alone courses and co-curricular enrichment opportunities. Courses offer the opportunity for depth and for conceptual learning but co-curricular programming offers experiential learning in a lowpressure, community-oriented atmosphere.

\section{CONCLUSION}

While we have regularly assessed the short-term impact of our curricular and co-curricular programing over the past decade and a half, our alumni impact study provides evidence that engineering leadership programming can and does catalyze long-lasting personal and professional growth for undergraduate and graduate students - all of whom are in a position to positively influence their workplaces and society. We will continue to develop leadership education that enhances the professional skills, self-development, and sense of broader responsibility among our students.

\section{References}
1. Reeve, D.W., et al., Curricular and co-curriular leadership learning for engineering students. Collected Essays on Learning and Teaching, 2015. 8(1): p. 41-56.
2. Simpson, A.E., G.J. Evans, and D.W. Reeve, $A$ summer leadership development program for

chemical engineering students. Journal of Leadership Education, 2012. 11(1): p. 222-232.

3. Kovalchuk, S., et al. Transitioning from university to employment in engineering: The role of curricular and co-curricular activities. in American Society of Engineering Education Annual Conference and Exposition 2017. Columbus, $\mathrm{OH}$.

4. Reeve, D.W., C. Rottmann, and R. Sacks. $A$ responsibility to promote leadership: Engineering entrepreneurs speak back to resistance. in Canadian Engineering Education Association Conference. 2014. Calgary, Alberta.

5. Reeve, D.W., C. Rottmann, and R. Sacks. The ebb and flow of engineering leadership orientations. in American Society of Engineering Education Annual Conference and Exposition. 2015. Seattle, WA.

6. Reeve, D.W., et al. Engineer leadership in organizations and the implications for curriculum development. in Canadian Engineering Education Association Conference. 2013. Montreal, QC.

7. Rottmann, C., et al. Examining the engineering leadership literature: Community of practice style. in American Society of Engineering Education Annual Conference and Exposition. 2018. Salt Lake City, UT.

8. Rottmann, C., et al. Engineering ethics education: More than a CEAB requirement. in Canadian Engineering Education Association. 2015. Hamilton, ON.

9. Rottmann, C., et al. Where's my code? Engineers navigating ethical issues on an uneven terrain. in American Society of Engineering Education Annual Conference and Exposition. 2018. Salt Lake City, UT.

10. Rottmann, C., et al., An intersubjective analysis of engineering leadership across organizational locations: Implications for higher education. Canadian Journal of Higher Education, 2016. 46(4): p. 146-173.

11. Rottmann, C., et al. Sports, arts and concrete canoes: Engineers learning to lead outside the formal curriculum. in American Society of Engineering Education's 123rd Annual Conference and Exposition. 2016. New Orleans, LA.

12. Rottmann, C., R. Sacks, and D.W. Reeve, Engineering leadership: Grounding leadership theory in engineers' professional identities. Leadership, 2015. 11(3): p. 351-373.

13. Rottmann, C., et al. Gendering engineering leadership: Aspirations vs. shoulder tapping in American Society of Engineering Education

CEEA19

University of Ottawa; June 9-12, 2019 
Annual Conference and Exposition. 2015.

Seattle, WA.

14. Sheridan, P.K., G.J. Evans, and D.W. Reeve. $A$

proposed framework for teaching team-

effectiveness in team-based projects. in American

Society for Engineering Education Conference

and Exposition. 2012. San Antonio, TX.

15. Sheridan, P.K., G.J. Evans, and D.W. Reeve.

Understanding teaching assistants' assessment of individual teamwork performance. in American

Society of Engineering Education Annual

Conference and Exposition. 2014. Indianapolis,

IN.

16. Sheridan, P.K., et al. The role of "togethering" in developing teamwork relationships and shared meaning. in American Society of Engineering Education Annual Conference and Exposition. 2015. Seattle, WA.

17. Sheridan, P.K., et al. Seeing into your teams: An instructor interface to support team learning. in Canadian Engineering Education Association. 2015. Hamilton, ON.

18. Klassen, M., et al. Charting the landscape of engineering leadership education in North American universities. in American Society of Engineering Education Annual Conference and Exposition. 2016. New Orleans, LA.

19. Komives, S.R., et al., A leadership identity development model: Applications from a grounded theory. Journal of College Student Development, 2006. 47(4): p. 401-418.

20. Sheridan, P.K., et al. A team-effectiveness inventory for guided reflection and feedback. in American Sciety for Engineeering Education Conference and Exposition. 2013. Atlanta, GA.

21. Rottmann, C., et al. "Counting past two:" Engineers' leadership learning trajectories. in American Society of Engineering Education Annual Conference and Exposition. 2019. Tampa, FL.

22. Schell, W.J. and B.E. Hughes. The potential of the leadership identity model to develop undergraduate engineering leadership: A theoretical approach. in American Society for Engineering Management 2016 International Annual Conference. 2016. Charlotte, NC: ASEM.

23. Colcleugh, D., Everyone a leader: A guide to leading high-performance organizations for engineers and scientists. 2013, Toronto, ON: University of Toronto Press.

24. Knight, D.B. and B.J. Novoselich, Curricular and Co-curricular influences on undergraduate engineering student leadership. Journal of Engineering Education, 2017. 106(1): p. 44-70.

\section{CEEA19}

University of Ottawa; June 9-12, 2019 